\title{
Discovery of A Fullerene-Polyoxometalate Hybrid Exhibiting Enhanced Photocurrent Response
}

Weidong Yu, ${ }^{\dagger} \mathrm{Li} \mathrm{Bin}^{\dagger}$, Yin Zhang, ${ }^{\dagger}$ Qianwen Yan $^{\dagger}$ and Jun Yan ${ }^{*},+\neq$

†College of Chemistry and Chemical Engineering, Central South University, Changsha 410083, P. R. China.

‡Hunan Provincial Key Laboratory of Efficient and Clean Utilization of Manganese Resources, Central South University, Changsha 410083, Hunan, China.

\section{Contents}

1. Experimental section

2. ${ }^{1} \mathrm{H}$ NMR spectra

3. FT-IR spectra

4. ESI-MS spectra

5. UV-vis titration

6. Raman spectra

7. Powder XRD

8.TEM image

9. Photocurrent response

10. UV-vis spectra and band gap 


\section{Experimental section}

The ${ }^{1} \mathrm{H}$ NMR spectra were performed on a Bruker Avance $400 \mathrm{MHz}$ spectrometer in Deuterium generation reagent with TMS as the inner standard. Fourier transform infrared (FT-IR) spectra were obtained on an Alpha Centauri FT-IR spectrometer in the $400-4000 \mathrm{~cm}^{-1}$ region with a $\mathrm{KBr}$ pellet. ESI mass spectra were recorded with a Bruker QTOF Qualification Standard Kit. Data analysis was performed on the Bruker IsotopePattern. Powder X-ray diffraction was employed using $\mathrm{Cu}-\mathrm{Ka}$ in the range of $10-50^{\circ}$ with the scanning rate of $10 \% / \mathrm{min}$. Electrochemical testing was performed on a CHI730E electrochemical workstation. The UV-vis spectra were obtained on a SHIMADZU UV-vis spectrophotometer. Raman spectra were performed on a Renishaw in Via with a red Spectra-Physics He-Ne laser (wavelength of 532). All reagents were purchased from commercial sources and used without further purification unless otherwise noted. The TEM images of the samples were taken with a JEOL 2010 Transmission Electron Microscope. The chemical composition of the synthesized compound was determined by induced coupled plasma optical emission spectrometry (ICP-OES) on a Leeman Prodigy instrument and by Perkin-EImer2400 CHN analyzer.

Synthesis of (TBA) $)_{4} \mathbf{K}\left[\mathrm{SiW}_{\mathbf{1 1}} \mathbf{M n}\left(\mathrm{H}_{\mathbf{2}} \mathrm{O}\right) \mathrm{O}_{39}\right]$ (1). (TBA $)_{5}\left[\mathrm{SiW}_{11} \mathrm{Mn}\left(\mathrm{H}_{2} \mathrm{O}\right) \mathrm{O}_{39}\right]$ was synthesized according to the literature ${ }^{[1]} .20 .0 \mathrm{~g} \mathrm{~K}_{8}\left[\mathrm{SiW}_{11} \mathrm{O}_{39}\right] \cdot 13 \mathrm{H}_{2} \mathrm{O}$ was dissolved in $40 \mathrm{~mL}$ water and the solution was heated to $95{ }^{\circ} \mathrm{C}$ while stirring (solution A). 1.8 $\mathrm{mL}$ of a $6.0 \mathrm{~mol} / \mathrm{L}$ solution of $\mathrm{HCl}$ was added to $20 \mathrm{~mL}$ water containing $0.196 \mathrm{~g}$ $\mathrm{KMnO}_{4}$ (solution B). $1.22 \mathrm{~g} \mathrm{Mn}\left(\mathrm{CH}_{3} \mathrm{COO}\right)_{2} \cdot 4 \mathrm{H}_{2} \mathrm{O}$ was dissolved in $20 \mathrm{~mL}$ water (solution $\mathrm{C}$ ). Solution $\mathrm{B}$ and solution $\mathrm{C}$ were added dropwise and simultaneously to solution A. The resultant solution was kept at $95^{\circ} \mathrm{C}$ for $30 \mathrm{~min}$. After cooling to room temperature, the insoluble solid was separated by filtration. The filtrate was concentrated to $10 \sim 12 \mathrm{~mL}$ and put in an ice bath for $3 \mathrm{~h}$, giving a pink solid, which was filtered off. The solid was redissolved in water and (TBA)Br was added to obtain a pink solid, 1. ${ }^{1} \mathrm{H}$ NMR $\left(400 \mathrm{MHz}, \mathrm{CD}_{3} \mathrm{CN}\right): \delta(\mathrm{ppm})=3.13\left(\mathrm{~m}, 2 \mathrm{H}\right.$ in $\left.\mathrm{TBA}^{+}\right)$, 1.63(m, $2 \mathrm{H}$ in $\left.\mathrm{TBA}^{+}\right), 1.39\left(\mathrm{~m}, 2 \mathrm{H}\right.$ in $\left.\mathrm{TBA}^{+}\right), 0.98\left(\mathrm{t}, 3 \mathrm{H}\right.$ in $\left.\mathrm{TBA}^{+}\right)$. ESI-MS data was shown in Figure S5 and Table S2. IR spectrum (KBr, pellets, $\left.\mathrm{cm}^{-1}\right): 792(\mathrm{~s}), 873(\mathrm{w})$, 917 (s), 956 (s), 1003(s). ICP-OES (\%): W, 53.0 (cal. 53.8), Mn, 1.4 (cal. 1.5), K, 0.9 (cal. 1.0). Elemental analysis (\%): C, 20.9 (cal. 20.4), H. 4.0 (cal. 3.9), N, 1.5 (cal. 1.4).

Synthesis of $\mathbf{C}_{60}(\mathbf{C N O})\left(\mathbf{C}_{5} \mathbf{H}_{4} \mathbf{N}\right) \quad$ (2). 4-pyridinecarboxaldoxime $\quad(0.0407 \mathrm{~g}$, $0.33 \mathrm{mmol})$ was added to a solution of the N-bromosuccinimide $(0.0594 \mathrm{~g}, 0.33 \mathrm{mmol})$ in $10 \mathrm{~mL}$ of DMF. The mixture was stirred for $1 \mathrm{~h}$ at room temperature and then added to a purple solution of $\mathrm{C}_{60}(0.2016 \mathrm{~g}, 0.28 \mathrm{mmol})$ in $90 \mathrm{~mL}$ of toluene. Triethylamine $(0.2 \mathrm{~mL})$ was added and the reaction was stirred for $3 \mathrm{~h}$ at room temperature. The resulting solution was evaporated by rotary evaporator and the residue was subjected to column chromatography on silica gel using toluene/petroleum ether as the eluent. The isolated products were dried overnight under vacuum at $80^{\circ} \mathrm{C}$ and obtained as brown powder in $38 \%$ yield $(89.4 \mathrm{mg})$ based on $\mathrm{C}_{60} .{ }^{1} \mathrm{H}$ NMR (400 MHz, $\left.\mathrm{C}_{6} \mathrm{D}_{5} \mathrm{CD}_{3}\right): 7.86\left(\mathrm{~d}, 2 \mathrm{H}\right.$ in $\left.\mathrm{C}_{5} \mathrm{H}_{4} \mathrm{~N}\right), 8.56\left(\mathrm{~d}, 2 \mathrm{H}\right.$ in $\left.\mathrm{C}_{5} \mathrm{H}_{4} \mathrm{~N}\right)$ ppm. ESI-MS ([M]-, m/z): theoretical for $\mathrm{C}_{66} \mathrm{H}_{4} \mathrm{~N}_{2} \mathrm{O}, 840.0329$; found, 840.0369. IR 
spectrum (KBr, pellets, $\mathrm{cm}^{-1}$ ): 2919 (w), 2848 (w), 1577 (s), 1467 (w), $1434(\mathrm{~m})$, 1330 (m), 997 (m), 865 (s), 770 (m). Elemental analysis (\%): C, 94.5 (cal. 94.2), H, 0.3 (cal. 0.5), N, 3.4 (cal. 3.3).

Synthesis of (TBA) $)_{4} \mathrm{~K}\left\{\mathrm{C}_{60}(\mathrm{CNO})\left(\mathrm{C}_{5} \mathrm{H}_{4} \mathrm{~N}\right)\left[\mathrm{SiW}_{11} \mathrm{O}_{39} \mathrm{Mn}\right]\right\}$ (3). 1 (1 equiv) and 2 (1.2 equiv) was added into acetonitrile/toluene $(50 \mathrm{~mL} / 50 \mathrm{~mL})$ and refluxed for $12 \mathrm{~h}$. After reaction, insoluble residue was filtered out, and the filtrate was evaporated to get the claybank residue. The crude product was washed with a large amount of toluene to remove the excess fullerene compound, resulting in the $\mathbf{3}$. (20\% yield, based on 2). ${ }^{1} \mathrm{H}$ NMR (400 MHz, $\left.\mathrm{CD}_{3} \mathrm{CN}\right): \delta(\mathrm{ppm})=7.98\left(\mathrm{~d}, 2 \alpha-\mathrm{H}\right.$ in $\left.\mathrm{C}_{5} \mathrm{H}_{4} \mathrm{~N}\right), 7.44$ $\left(\mathrm{d}, 2 \beta-\mathrm{H}\right.$ in $\left.\mathrm{C}_{5} \mathrm{H}_{4} \mathrm{~N}\right), 3.14\left(\mathrm{~m}, 2 \mathrm{H}\right.$ in $\left.\mathrm{TBA}^{+}\right), 1.64\left(\mathrm{~m}, 2 \mathrm{H}\right.$ in $\left.\mathrm{TBA}^{+}\right), 1.40(\mathrm{~m}, 2 \mathrm{H}$ in $\left.\mathrm{TBA}^{+}\right), 0.98\left(\mathrm{~m}, 3 \mathrm{H}\right.$ in $\left.\mathrm{TBA}^{+}\right)$. ESI-MS data was shown in Figure S8, S10 and Table S4, S6. IR spectrum (KBr, pellets, $\left.\mathrm{cm}^{-1}\right)$ : 708 (w), 761 (w), 799 (s), 901 (s), 963 (s), 998 (s). ICP-OES (\%): W, 44.4 (cal, 44.9), Mn, 1.3 (cal, 1.2), K, 1.0 (cal, 0.8). Elemental analysis (\%): C, 33.8 (cal, 34.1), H, 3.5 (cal, 3.2), N, 2.0 (cal, 1.8).

Mixture 4. For comparison purposes, compound 1 and $\mathbf{2}$ were grinded at the ratio of 1:1 in a mortar for half an hour, and named as mixture 4.

Photocurrent response experiment. All photoelectrochemical experiments were performed on a $\mathrm{CHI730E}$ electrochemical workstation at room temperature with a 400W Xe lamp $(\lambda>400 \mathrm{~nm})$ as the light source. A three-electrode system was employed in a $0.5 \mathrm{M} \mathrm{Na}_{2} \mathrm{SO}_{4}$ solution. Using $\mathrm{Ag} / \mathrm{AgCl}$ as the reference electrode, $\mathrm{Pt}$ wire as the counter electrode and ITO coated with sample as the working electrode. The sample $(0.01 \mathrm{mM})$ were dispersed in ethanol $(2 \mathrm{~mL})$ and the solution was ultrasonic for one hour to form a uniform suspension. $200 \mu \mathrm{L}$ of the suspension dripped onto a $3.5 \mathrm{~cm} \times 1.5 \mathrm{~cm}$ ITO, and only half of the ITO were in the solution.

\section{2. ${ }^{1} \mathrm{H}$ NMR spectra.}




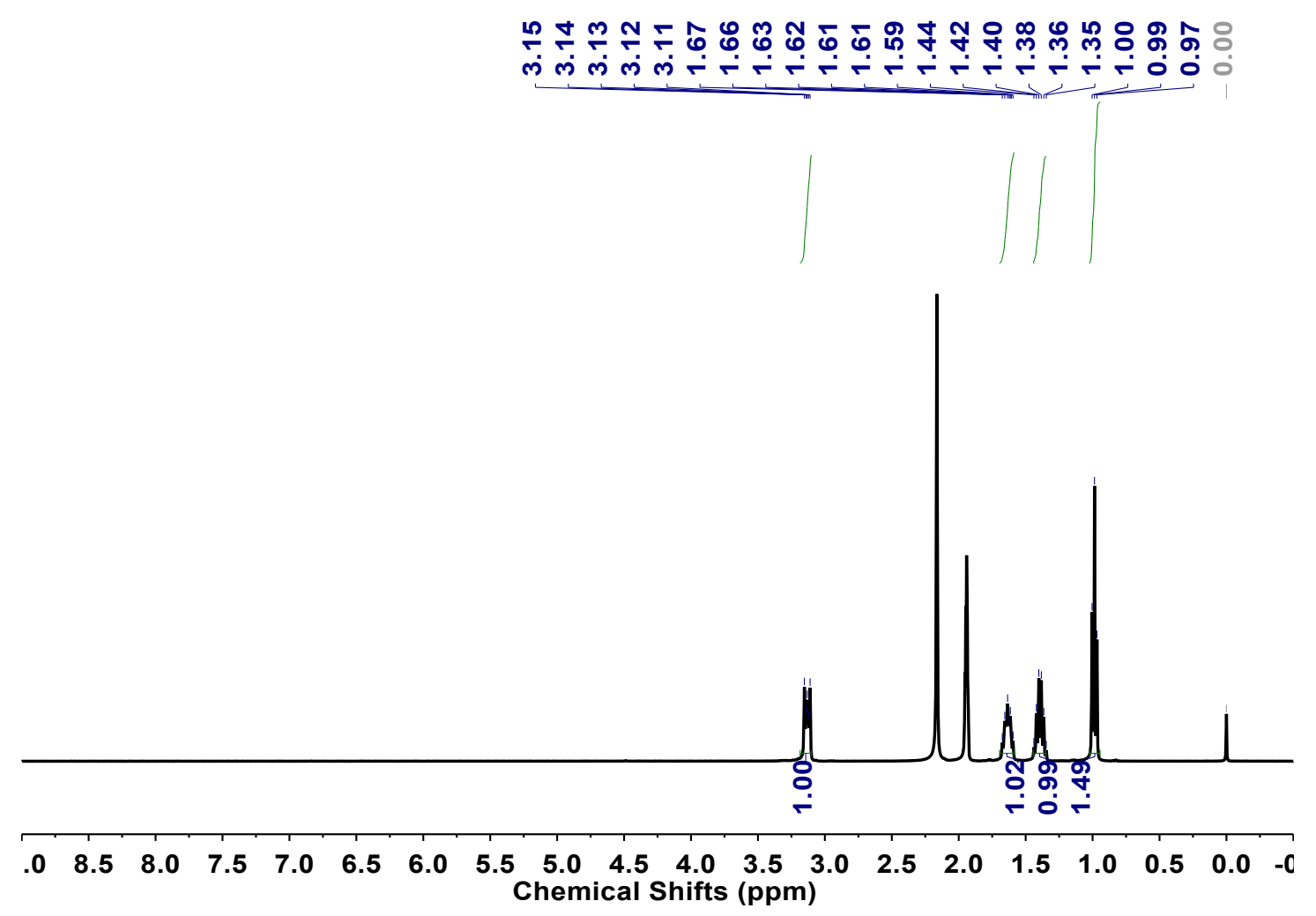

Figure S1. ${ }^{1} \mathrm{H}$ NMR spectrum of 1 in $\mathrm{CD}_{3} \mathrm{CN}$.

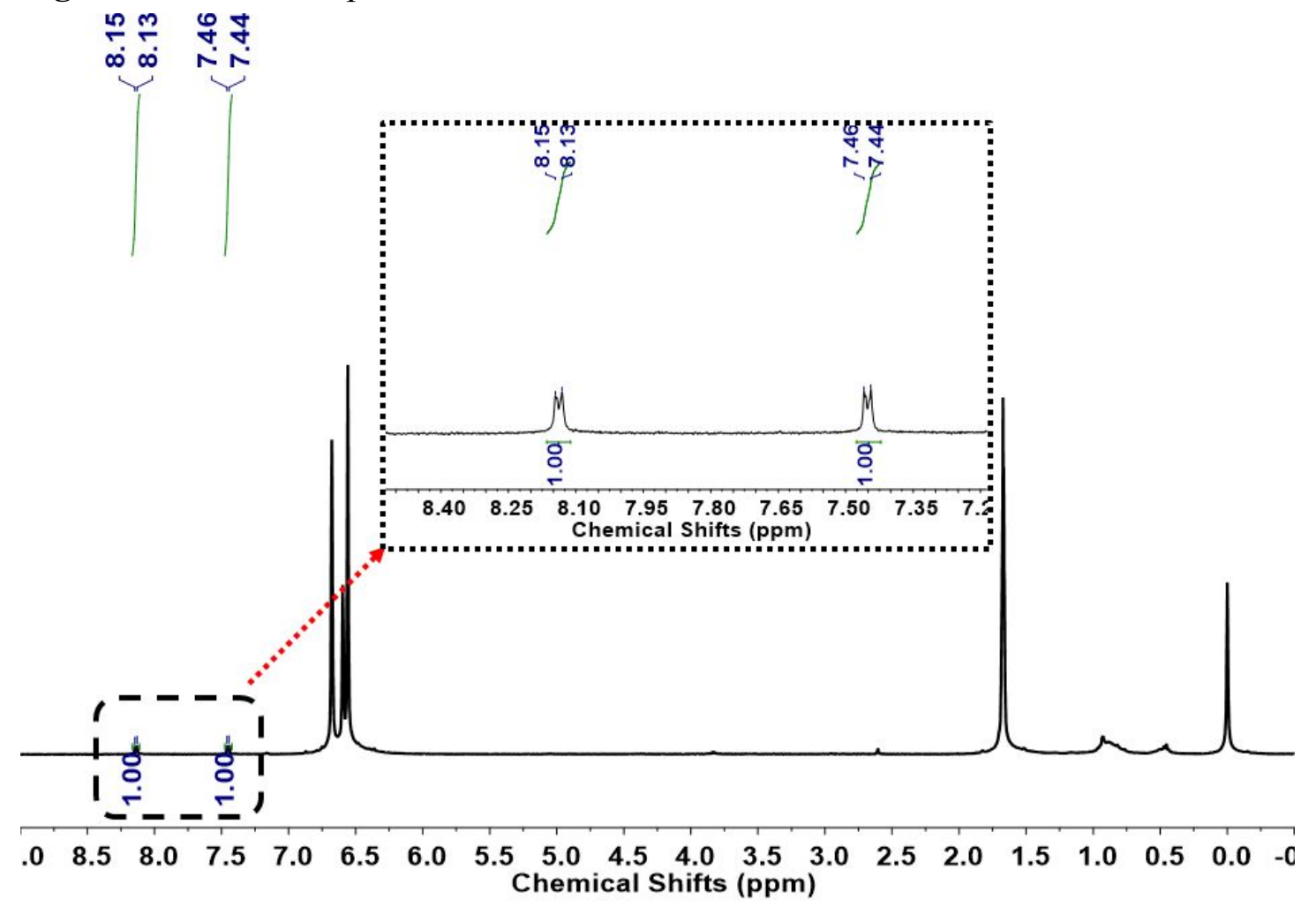

Figure S2. ${ }^{1} \mathrm{H}$ NMR spectrum of 2 in $\mathrm{C}_{6} \mathrm{D}_{5} \mathrm{CD}_{3}$. 

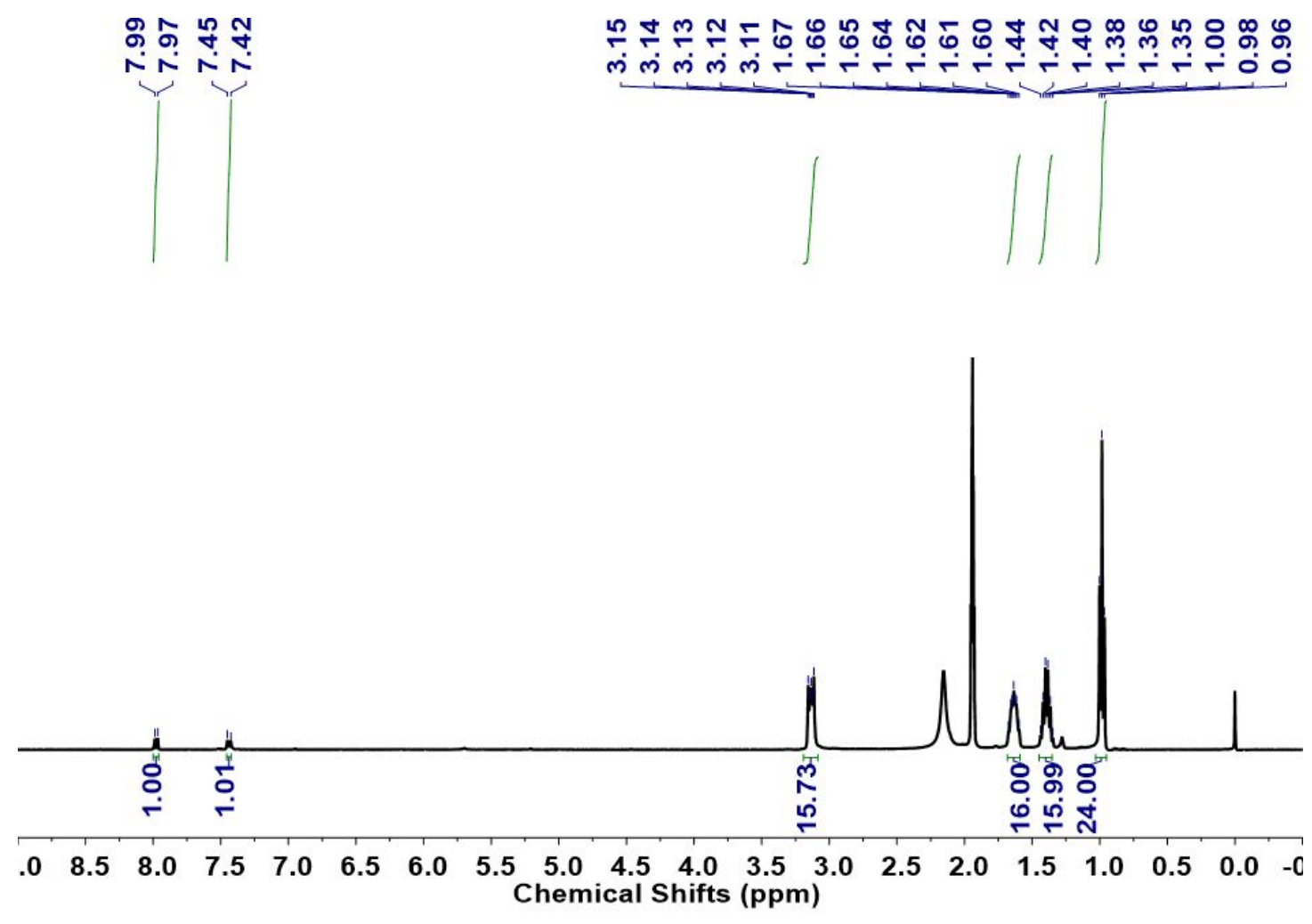

Figure S3. ${ }^{1} \mathrm{H}$ NMR spectrum of 3 in $\mathrm{CD}_{3} \mathrm{CN}$. 


\section{FT-IR spectra}
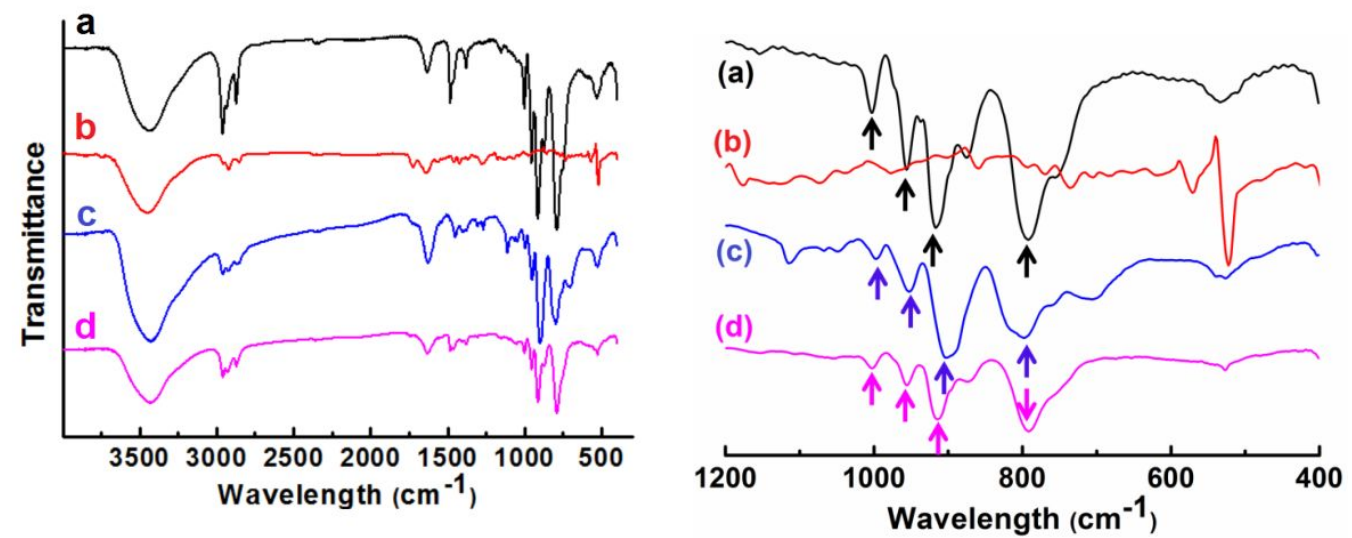

Figure S4. (left) The wavelength range is from $400 \mathrm{~cm}^{-1}$ to $4000 \mathrm{~cm}^{-1}$ of (a) 1, (b) 2 , (c) 3 and (d) 4; (right) The wavelength range is from $400 \mathrm{~cm}^{-1}$ to $1200 \mathrm{~cm}^{-1}$ of (a) $\mathbf{1}$, (b) 2 , (c) 3 and (d) 4 .

Table S1. The transmittance peaks of different compound according to FT-IR spectra.

\begin{tabular}{ccccc}
\hline & $\mathrm{W}_{-} \mathrm{O}_{\mathrm{d}}-\mathrm{W}$ & $\mathrm{W}-\mathrm{O}_{\mathrm{c}}-\mathrm{W}$ & $\mathrm{W}=\mathrm{O}_{\mathrm{d}}$ & $\mathrm{Si}-\mathrm{O}_{\mathrm{a}}$ \\
\hline $\mathbf{1}$ & $792 \mathrm{~cm}^{-1}$ & $917 \mathrm{~cm}^{-1}$ & $956 \mathrm{~cm}^{-1}$ & $1003 \mathrm{~cm}^{-1}$ \\
$\mathbf{3}$ & $799 \mathrm{~cm}^{-1}$ & $901 \mathrm{~cm}^{-1}$ & $963 \mathrm{~cm}^{-1}$ & $998 \mathrm{~cm}^{-1}$ \\
$\mathbf{4}$ & $792 \mathrm{~cm}^{-1}$ & $917 \mathrm{~cm}^{-1}$ & $956 \mathrm{~cm}^{-1}$ & $1003 \mathrm{~cm}^{-1}$ \\
\hline
\end{tabular}




\section{ESI-MS spectra}

3-

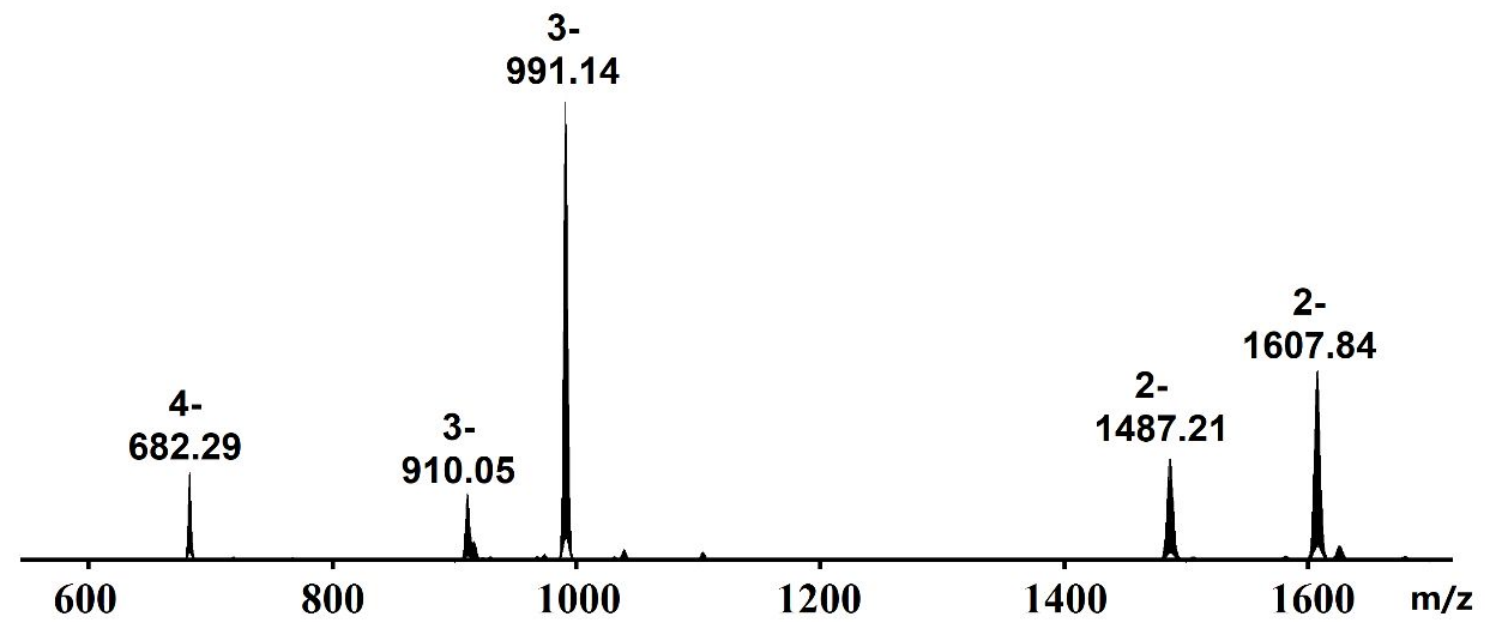

Figure S5. ESI-MS spectrum at negative mode of 1.
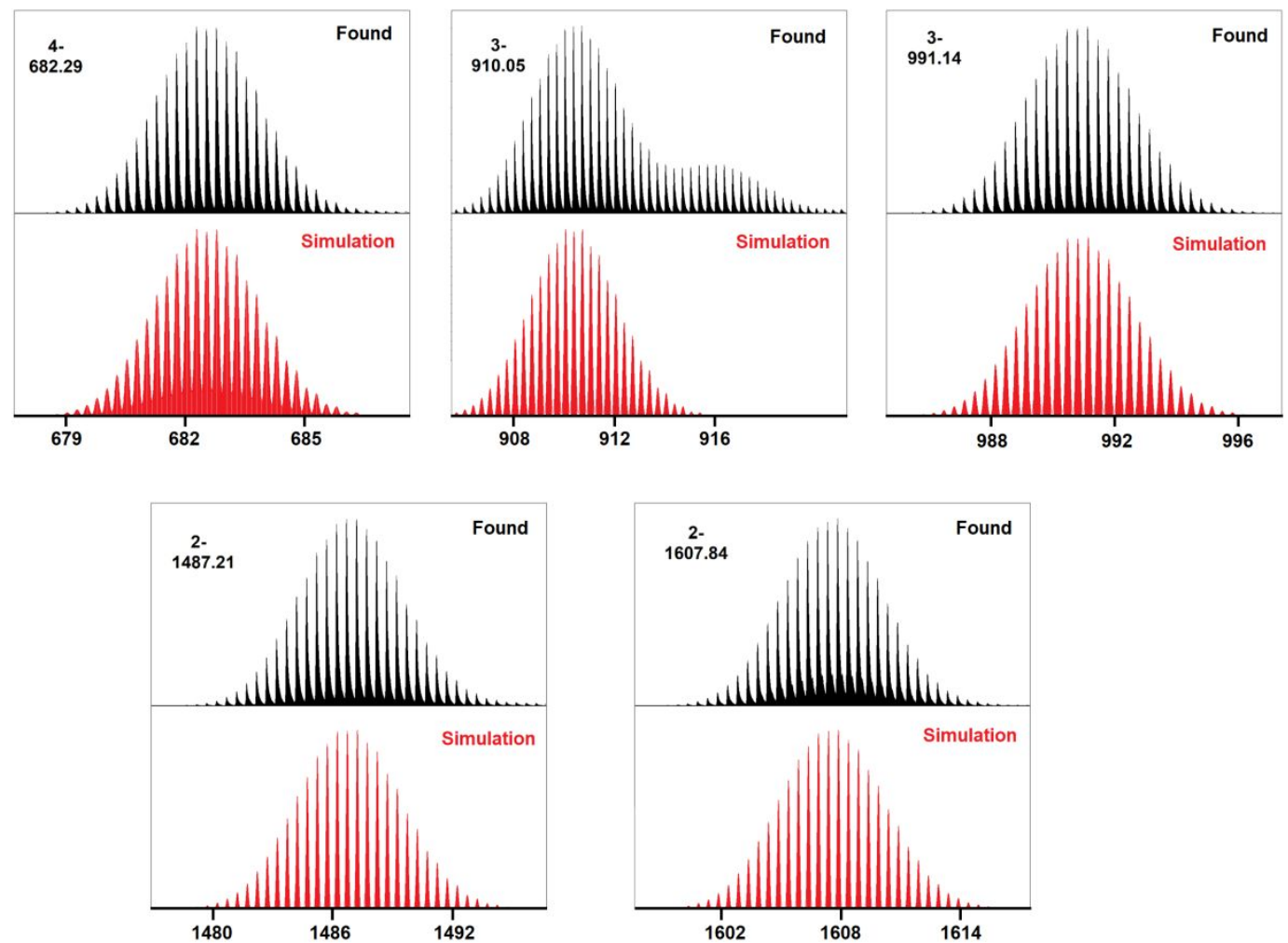

Figure S6. The main peaks of ESI-MS spectra of 1 at negative mode, and the corresponding simulation diagrams. 
Table S2. Assignments of major peaks for the ESI-MS spectrum at negative mode analysis of 1 according to Figure S5.

\begin{tabular}{ccc}
\hline Formula & Theoretical & Found \\
\hline $\mathrm{H}\left[\mathrm{MnSiW}_{11} \mathrm{O}_{39}\right]^{4-}$ & 682.30 & 682.29 \\
$\mathrm{H}_{2}\left[\mathrm{MnSiW}_{11} \mathrm{O}_{39}\right]^{3-}$ & 910.06 & 910.05 \\
$\mathrm{H}(\mathrm{TBA})\left[\mathrm{MnSiW}_{11} \mathrm{O}_{39}\right]^{3-}$ & 991.16 & 991.14 \\
$\mathrm{H}_{2}(\mathrm{TBA})\left[\mathrm{MnSiW}_{11} \mathrm{O}_{39}\right]^{2-}$ & 1487.24 & 1487.21 \\
$\mathrm{H}(\mathrm{TBA})_{2}\left[\mathrm{MnSiW}_{11} \mathrm{O}_{39}\right]^{2-}$ & 1607.88 & 1607.84 \\
\hline
\end{tabular}

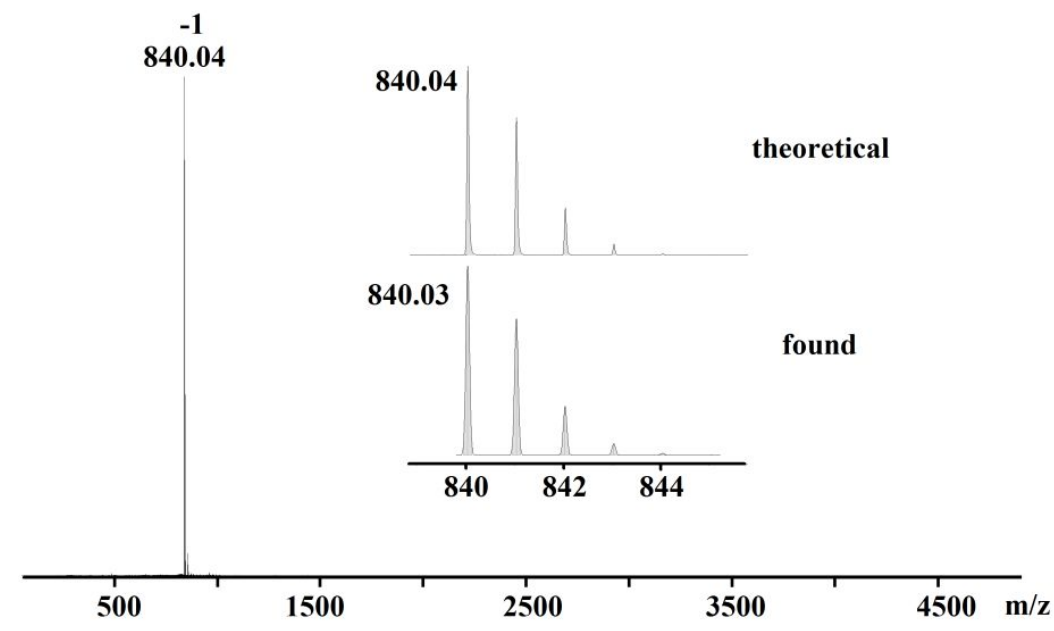

Figure S7. ESI-MS spectrum at negative mode of 2. Found 2-: 840.04; theoretical: 840.03 . 


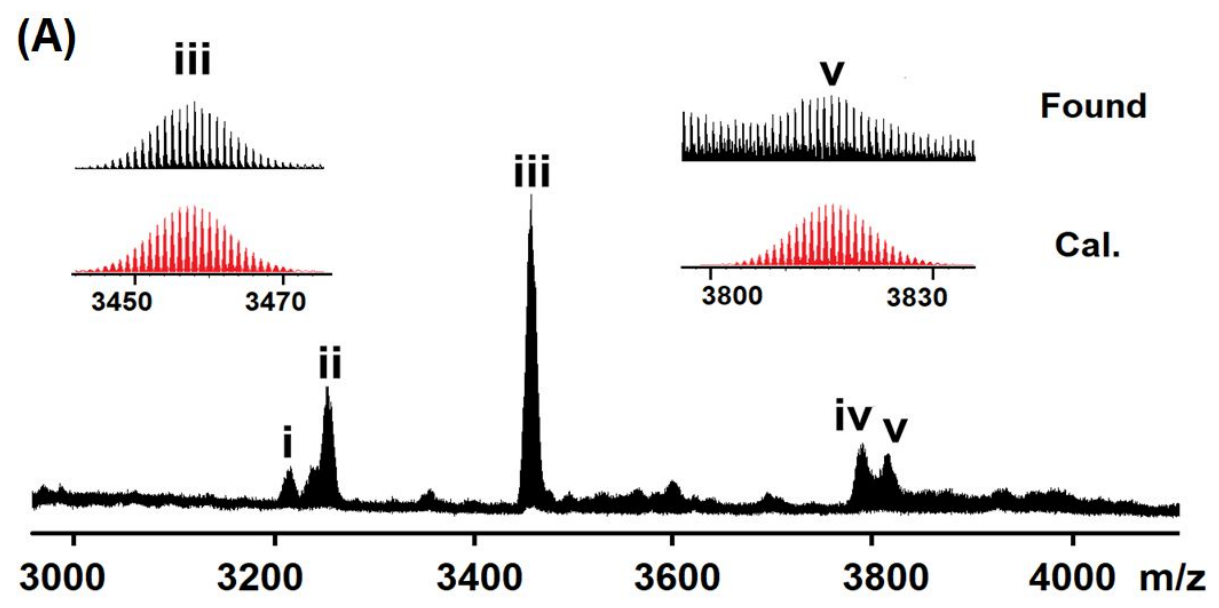

(B)

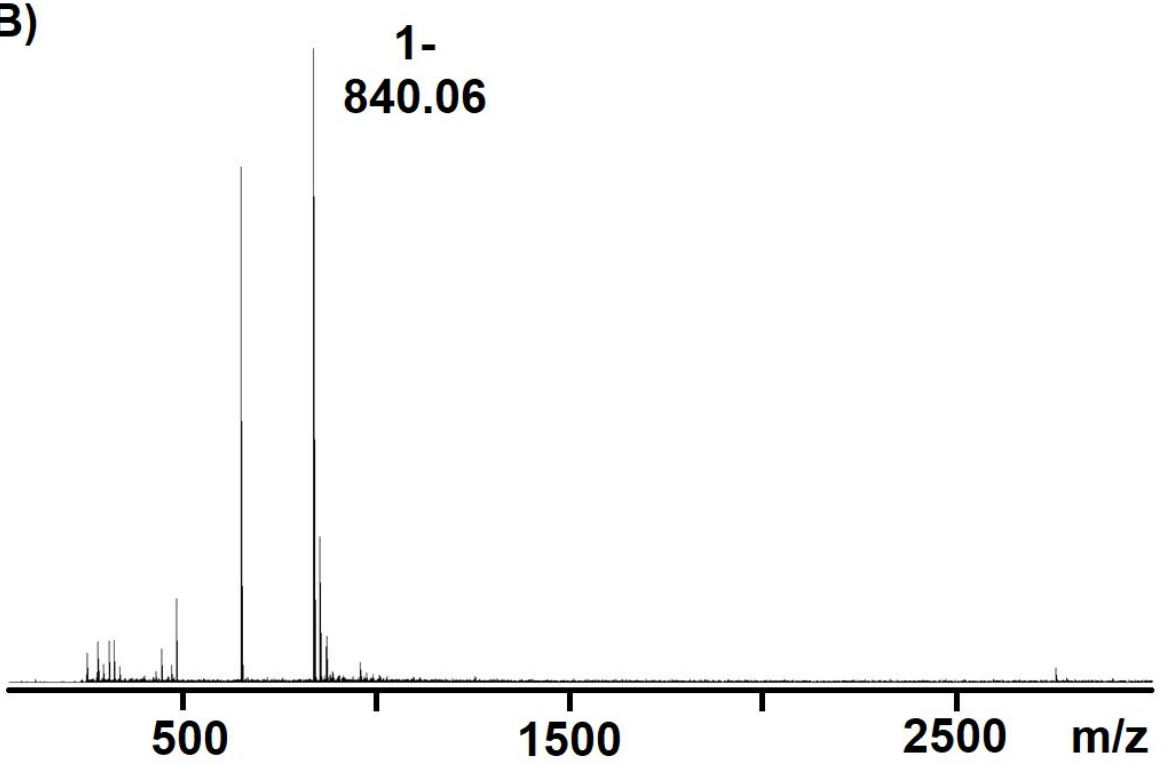

Figure S8. ESI-MS spectrum at negative mode of 3. (A) At the $\mathrm{m} / \mathrm{z}$ range of 3000 4000, and the insert showing the experimental and calculate isotopic patterns of peak iii and v. The test conditions: Collision energy: $30.0 \mathrm{eV}$, Collision cell RF: 4200 Vpp, Transfer time: $120.0 \mu \mathrm{s}$, PrePulseStorage time: $30.0 \mu \mathrm{s}$; (B) At the $\mathrm{m} / \mathrm{z}$ range of 100 3000. The test conditions: Collision energy: $20.0 \mathrm{eV}$, Collision cell RF :2500 Vpp, Transfer time: $200.0 \mu$ s, PrePulseStorage time: $10.0 \mu$ s.

3 was tested by ESI-MS in $\mathrm{CH}_{3} \mathrm{CN}$. During the test, 3 can be decomposed into 1 and $\mathbf{2}$, and under different test conditions, the ion fragment peaks of $\mathbf{1}$ and $\mathbf{2}$ can be observed in Figure S8 (A) and (B), respectively. 

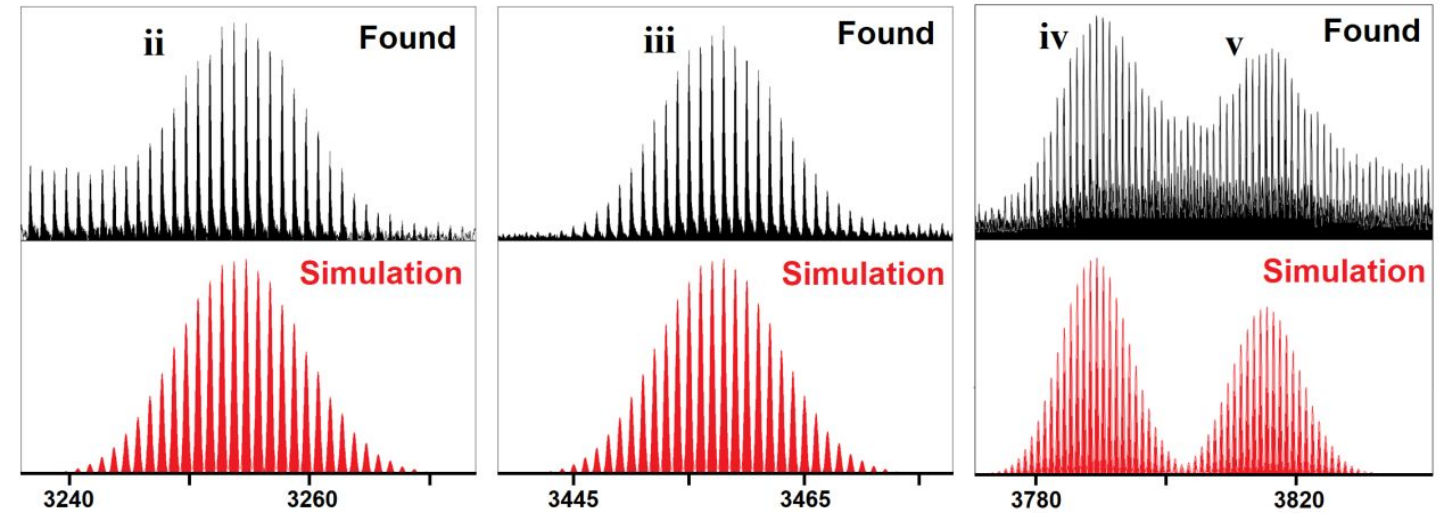

Figure S9. The main peaks of ESI-MS spectra of 3 at negative mode, and the corresponding simulation diagrams.

Table S3. Assignments of major peaks for the ESI-MS spectrum at negative mode analysis of $\mathbf{3}$ according to Figure S8(A).

\begin{tabular}{cccc}
\hline Peak & Found & Assignment & Theoretical \\
\hline i & 3216.75 & $\mathrm{H}_{2}(\mathrm{TBA})_{2}\left[\mathrm{MnSiW}_{11} \mathrm{O}_{39}\right]^{-}$ & 3216.77 \\
ii & 3254.72 & $\mathrm{KH}(\mathrm{TBA})_{2}\left[\mathrm{MnSiW}_{11} \mathrm{O}_{39}\right]^{-}$ & 3254.72 \\
iii & 3458.03 & $\mathrm{H}(\mathrm{TBA})_{3}\left[\mathrm{MnSiW}_{11} \mathrm{O}_{39}\right]^{-}$ & 3458.04 \\
iv & 3789.33 & $(\mathrm{TBA})_{4}\left[\mathrm{MnSiW}{ }_{11} \mathrm{O}_{39}\right]\left(\mathrm{H}_{2} \mathrm{O}\right)_{5}^{-}$ & 3789.37 \\
v & 3816.34 & $\mathrm{H}_{3}(\mathrm{TBA})\left[\mathrm{MnSiW}_{11} \mathrm{O}_{39}(\mathbf{2})\right]^{-}$ & 3816.37 \\
\hline
\end{tabular}

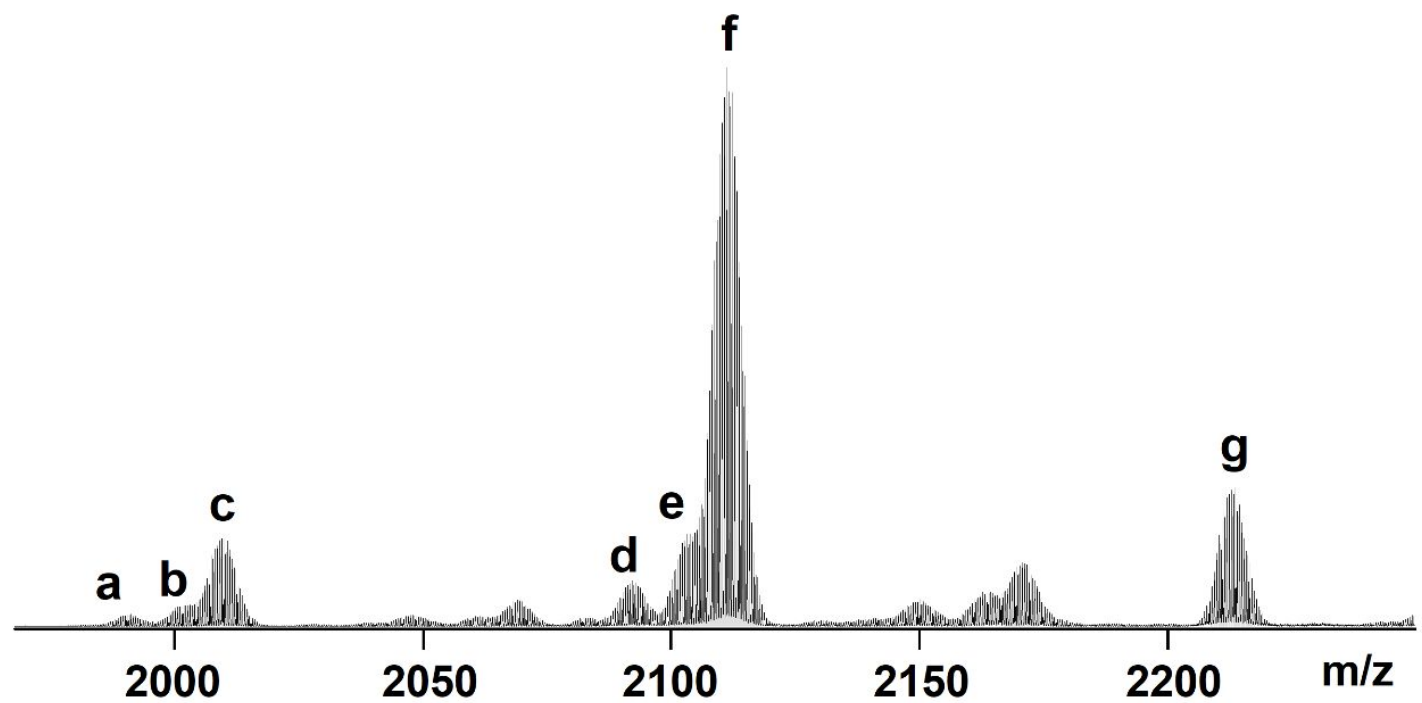

Figure S10. ESI-MS spectrum at positive mode of 1. 

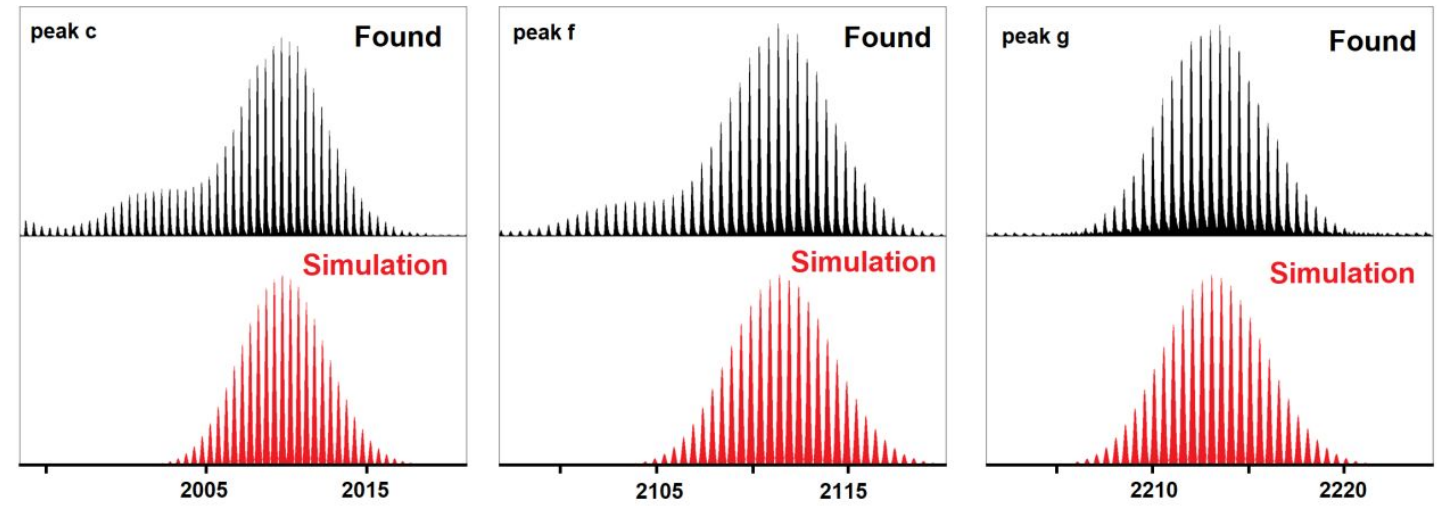

Figure S11. The main peaks of ESI-MS spectra of 1 at positive mode, and the corresponding simulation diagrams.

Table S4. Assignments of major peaks for the ESI-MS spectrum at positive mode analysis of $\mathbf{1}$ according to Figure S10.

\begin{tabular}{cccc}
\hline Peak & Experimentally & Formula & Theoretically \\
\hline a & 1990.73 & $\mathrm{KH}(\mathrm{TBA})_{5}\left[\mathrm{MnSiW11O}{ }_{39}\right]^{2+}$ & 1990.79 \\
b & 2001.72 & $\mathrm{KNa}(\mathrm{TBA})_{5}[\mathrm{MnSiW11O} 39]^{2+}$ & 2001.78 \\
c & 2009.71 & $\mathrm{~K}_{2}(\mathrm{TBA})_{5}\left[\mathrm{MnSiW} 11 \mathrm{O}_{39}\right]^{2+}$ & 2009.77 \\
d & 2092.39 & $\mathrm{H}(\mathrm{TBA})_{6}\left[\mathrm{MnSiW} 11 \mathrm{O}_{39}\right]^{2+}$ & 2092.45 \\
e & 2103.38 & $\mathrm{Na}(\mathrm{TBA})_{6}\left[\mathrm{MnSiW11O}{ }_{39}\right]^{2+}$ & 2103.44 \\
f & 2111.36 & $\mathrm{~K}(\mathrm{TBA})_{6}\left[\mathrm{MnSiW} 11 \mathrm{O}_{39}\right]^{2+}$ & 2111.43 \\
g & 2213.02 & $(\mathrm{TBA})_{7}\left[\mathrm{MnSiW} 11 \mathrm{O}_{39}\right]^{2+}$ & 2213.09 \\
\hline
\end{tabular}

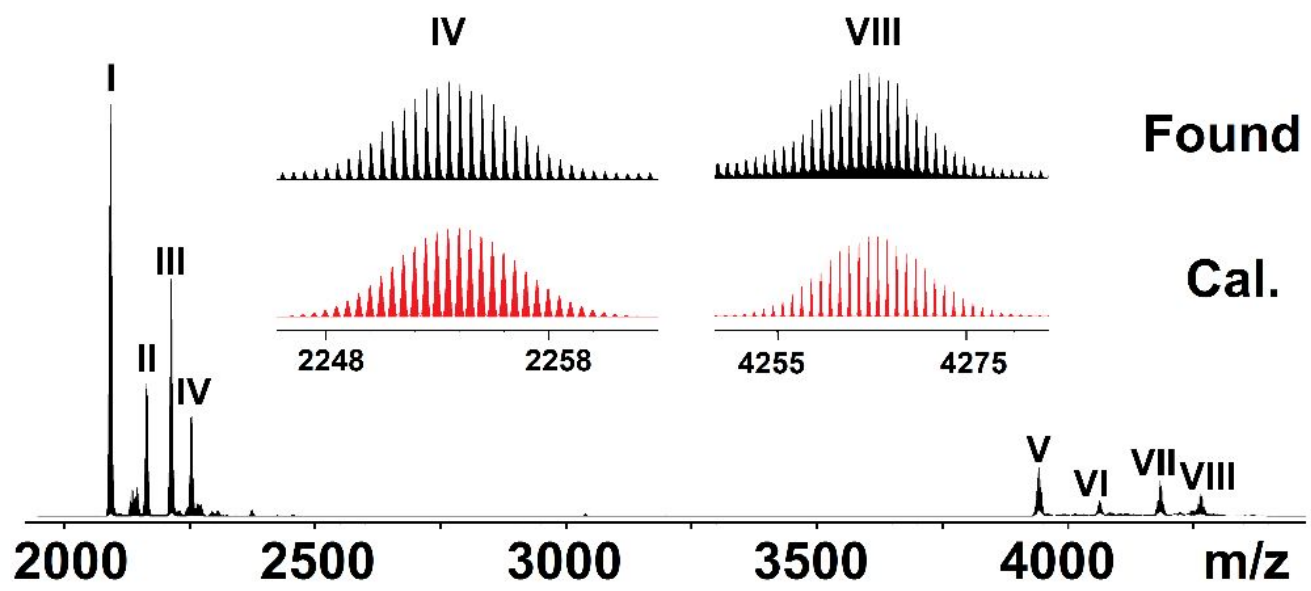

Figure S12. ESI-MS spectrum at positive mode of $\mathbf{3}$. 
(a)

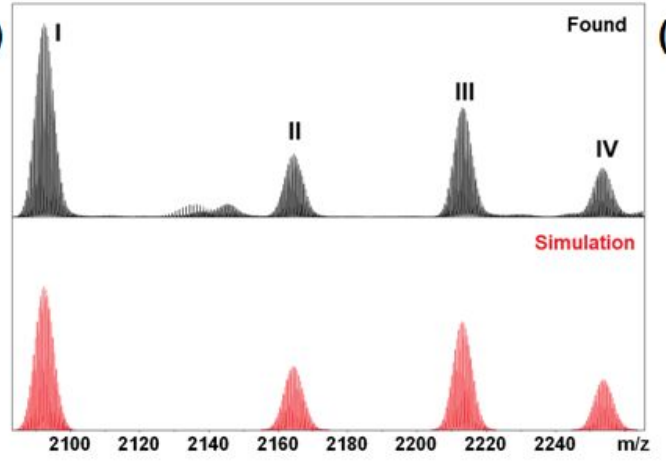

(b)

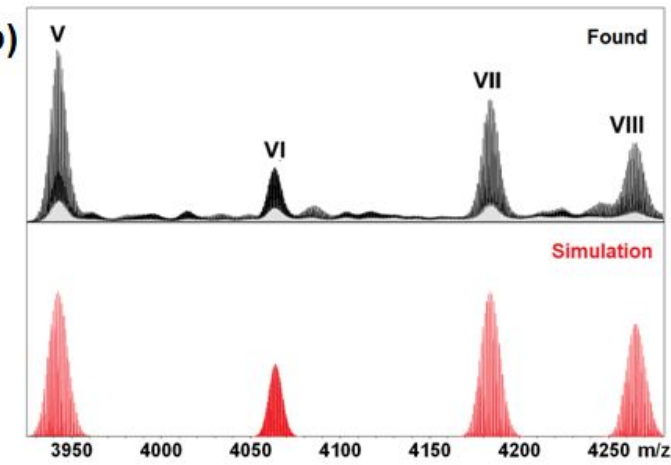

Figure S13. The main peaks of ESI-MS spectra of $\mathbf{3}$ at positive mode, and the corresponding simulation diagrams.

Table S5. Assignments of major peaks for the ESI-MS spectrum at positive mode analysis of $\mathbf{3}$ according to Figure S12.

\begin{tabular}{|c|c|c|c|}
\hline Peak & Found & Formula & Calculate \\
\hline $\mathbf{I}$ & 2092.42 & $(\mathrm{TBA})_{6} \mathrm{H}\left[\mathrm{MnSiW}_{11} \mathrm{O}_{39}\right]^{2+}$ & 2092.45 \\
\hline II & 2164.42 & $(\mathrm{TBA})_{6}\left[\mathrm{SiW}_{12} \mathrm{O}_{40}\right]^{2+}$ & 2164.45 \\
\hline III & 2213.05 & $(\mathrm{TBA})_{7}\left[\mathrm{MnSiW}_{11} \mathrm{O}_{39}\right]^{2+}$ & 2213.09 \\
\hline IV & 2254.02 & $(\mathrm{TBA})_{3} \mathrm{~K}_{4}\left[\mathrm{MnSiW}_{11} \mathrm{O}_{39}(2)\right]\left(\mathrm{H}_{2} \mathrm{O}\right)_{3}{ }^{2+}$ & 2253.98 \\
\hline $\mathbf{V}$ & 3942.54 & $(\mathrm{TBA})_{5} \mathrm{H}\left[\mathrm{MnSiW}_{11} \mathrm{O}_{39}\right]^{+}$ & 3942.61 \\
\hline VI & 4063.69 & $\left\{(\mathrm{TBA}) \mathrm{K}_{5}\left[\mathrm{MnSiW}_{11} \mathrm{O}_{39}(\mathbf{2})\right]\left(\mathrm{H}_{2} \mathrm{O}\right)_{4}\right\}_{2}{ }^{2+}$ & 4063.88 \\
\hline VII & 4183.82 & $(\mathrm{TBA})_{6}\left[\mathrm{MnSiW}_{11} \mathrm{O}_{39}\right]^{+}$ & 4183.89 \\
\hline VIII & 4264.73 & $(\mathrm{TBA})_{2} \mathrm{~K}_{4}\left[\mathrm{MnSiW}_{11} \mathrm{O}_{39}(\mathbf{2})\right]\left(\mathrm{H}_{2} \mathrm{O}\right)_{3}{ }^{+}$ & 4264.67 \\
\hline
\end{tabular}

\section{UV-vis titration}
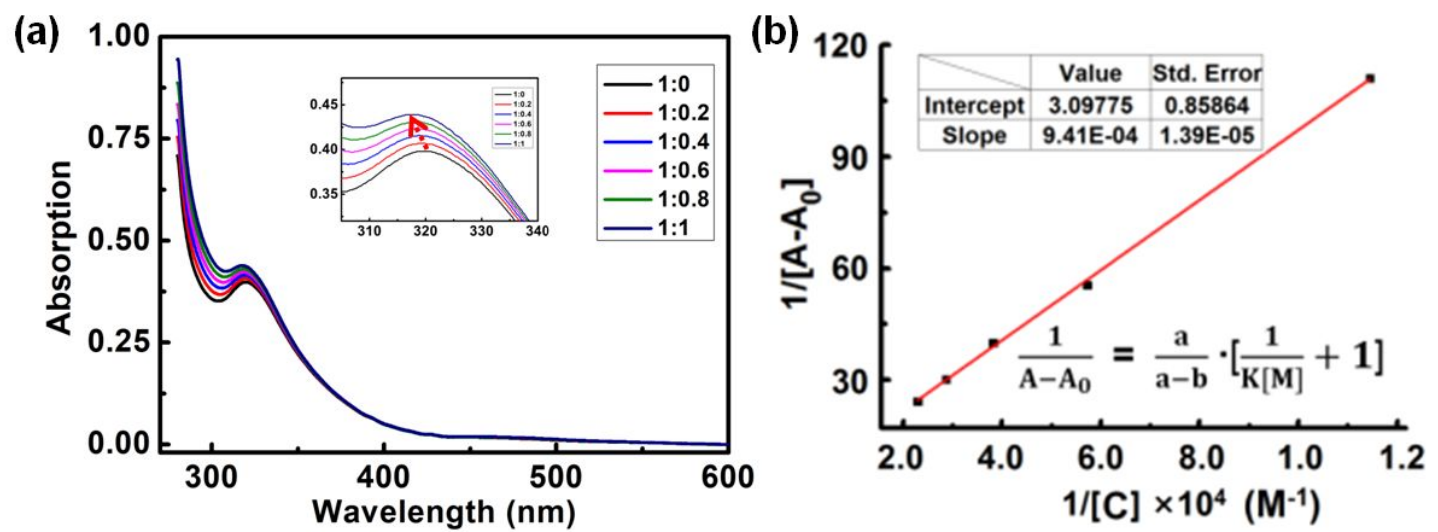

Figure S14. (a) UV-vis spectra changes during increasing addition of $1\left(8.74 \times 10^{-6} \mathrm{M}\right.$ each addition) to a solution of $2\left(4.37 \times 10^{-5} \mathrm{M}\right)$ in $\mathrm{CH}_{3} \mathrm{CN} /$ toluene $(2: 1)$, the ratio was 2 against 1. (b) Benesi-Hildebrand plot constructed to evaluate the binding constant. $\mathrm{A}$ and $\mathrm{A}_{0}$ represent the absorbance of $\mathbf{2}$ in the absence and presence, respectively, of added 1. 


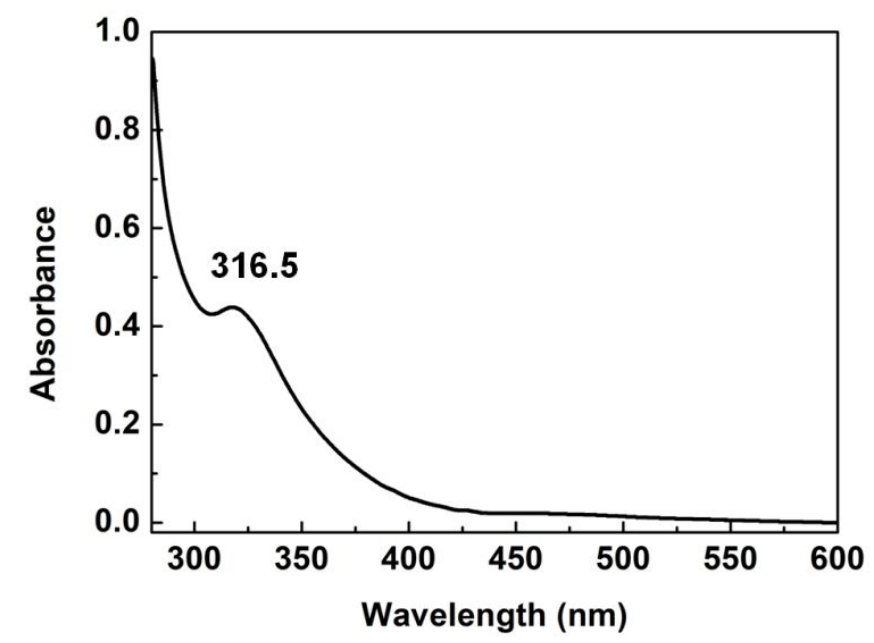

Figure S15. The UV-vis spectra of $3\left(4.37 \times 10^{-5} \mathrm{M}\right)$ in $\mathrm{CH}_{3} \mathrm{CN} /$ toluene $(2: 1)$.

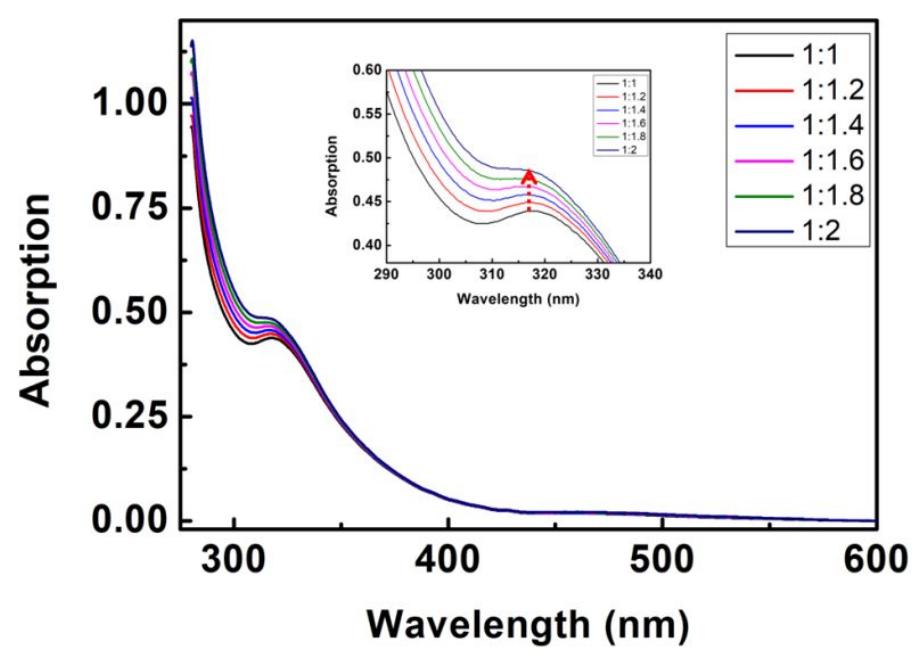

Figure S16. UV-vis spectra changes during increasing addition of $1\left(8.74 \times 10^{-6} \mathrm{M}\right.$ each addition) to a mixture solution $\left(\mathrm{CH}_{3} \mathrm{CN} /\right.$ toluene $\left.=2: 1\right)$ containing $\mathbf{2}$ and $\mathbf{1}$ (each $\left.4.37 \times 10^{-5} \mathrm{M}\right)$, the ratio was 2 against 1 .

UV-vis titration was performed in $10 \mathrm{~mL}$ mixture solution A containing $4.37 \times 10^{-5}$ $\mathrm{M}$ of 2. $100 \mu \mathrm{L}$ solution B containing $1\left(8.74 \times 10^{-4} \mathrm{M}\right)$ was added each time. Since the added volume of B was much smaller than that of $\mathrm{A}$, the volume of A was considered as constant, and the added concentration 1 was $8.74 \times 10^{-6} \mathrm{M}$ each time. Although the concentration was changed, the chemical shifts may be considered as not affect by this factor. The equation was list as follows: 
$1 / \Delta \delta=1 /\left(\mathrm{K} \cdot \Delta \delta_{\max } \cdot[\mathrm{H}]_{0}\right)+1 / \Delta \delta_{\max }$

Where $\Delta \delta=\left(\delta_{\mathrm{G}}-\delta_{\mathrm{obs}}\right)$;

$\Delta \delta_{\max }=\left(\delta_{\mathrm{G}}-\delta_{\mathrm{HG}}\right)$

$\delta_{\text {obs }}$ is an experimentally measured chemical shift;

$\delta_{\mathrm{G}}$ is the chemical shift of a nucleus in the guest molecule;

$\delta_{\mathrm{HG}}$ is the chemical shift of a nucleus in the host-guest complex;

$\Delta \delta$ is the measured change in chemical shift (upon addition of host species) referenced to that of the uncomplexed guest;

$\Delta \delta_{\max }$ is the difference in chemical shifts between that observed in the guest molecule and that observed in the host-guest complex;

$[\mathrm{H}]$ is the concentration of host at equilibrium;

$\mathrm{K}$ is the binding constant. 


\section{Raman spectra}

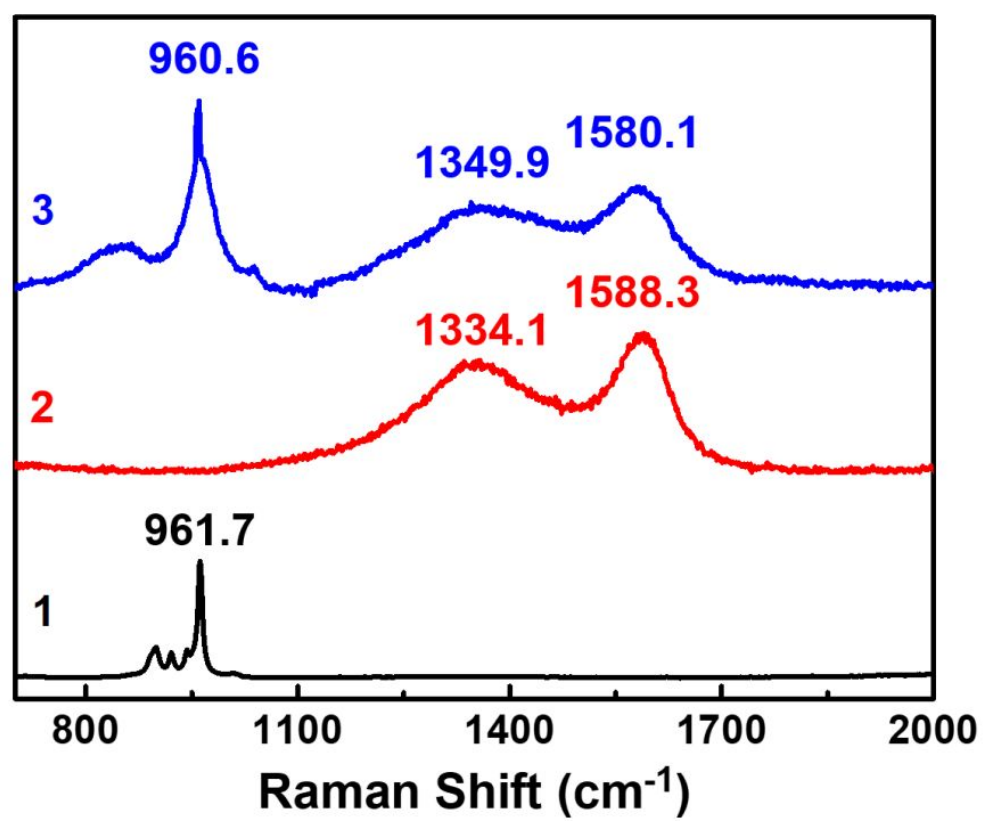

Figure S17. Raman spectra of 1 (black), 2 (red) and $\mathbf{3}$ (blue).

The peaks of 1 at $895.0 \sim 961.7 \mathrm{~cm}^{-1}$ were assigned to $v(\mathrm{~W}-\mathrm{O})$ of $\left\{\mathrm{SiW}_{11} \mathrm{MnO}_{39}\right\}$. The peaks of 2 at $1334.1 \sim 1588.3 \mathrm{~cm}^{-1}$ were assigned to $v(\mathrm{C}-\mathrm{C})$ of fullerene. When 1 and $\mathbf{2}$ coordinated as compound 3, the peak of POMs shifted from 961.7 to 960.6 , and the peaks of fullerene shifted from 1334.1 and 1588.3 to 1349.9 and 1580.1, respectively.

\section{Powder XRD}

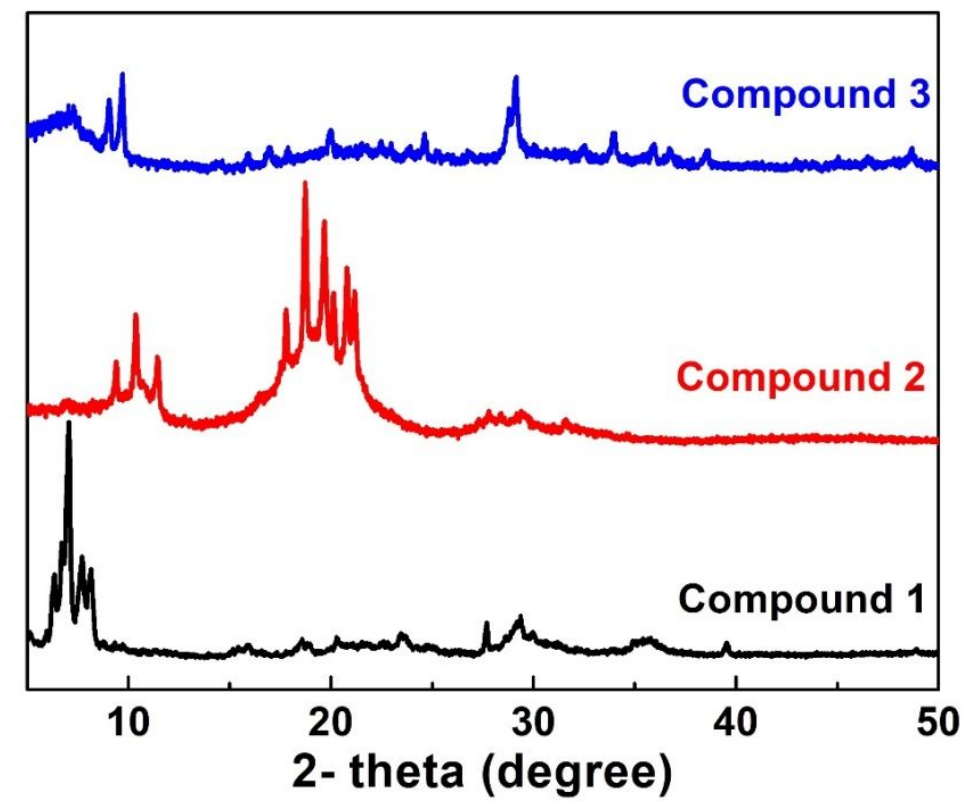

Figure S18. Powder XRD sepctra of 1, 2 and 3. 


\section{TEM image}
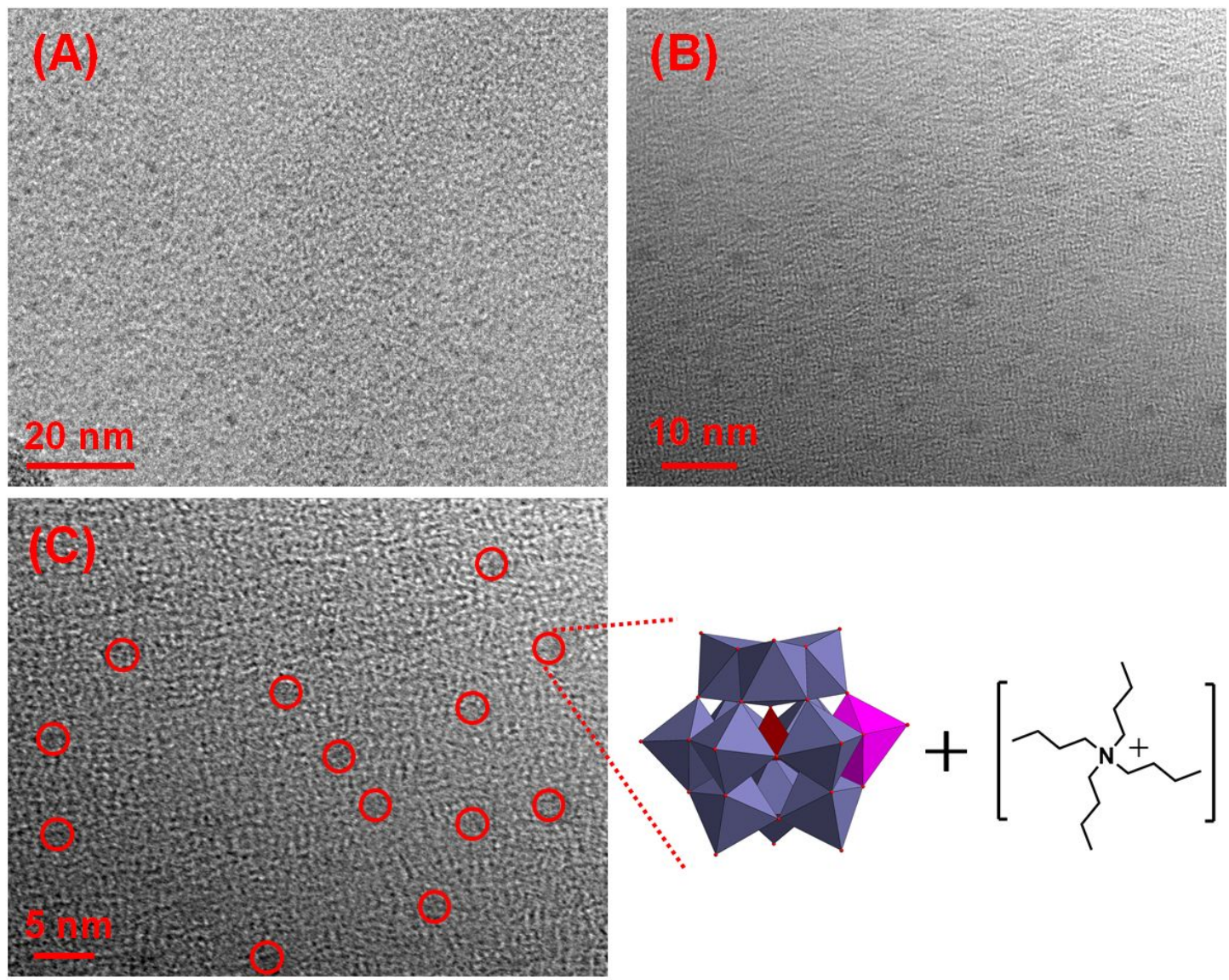

Figure S19. TEM image of 1 under (A) $20 \mathrm{~nm}$; (B) $10 \mathrm{~nm}$; (C) $5 \mathrm{~nm}$.

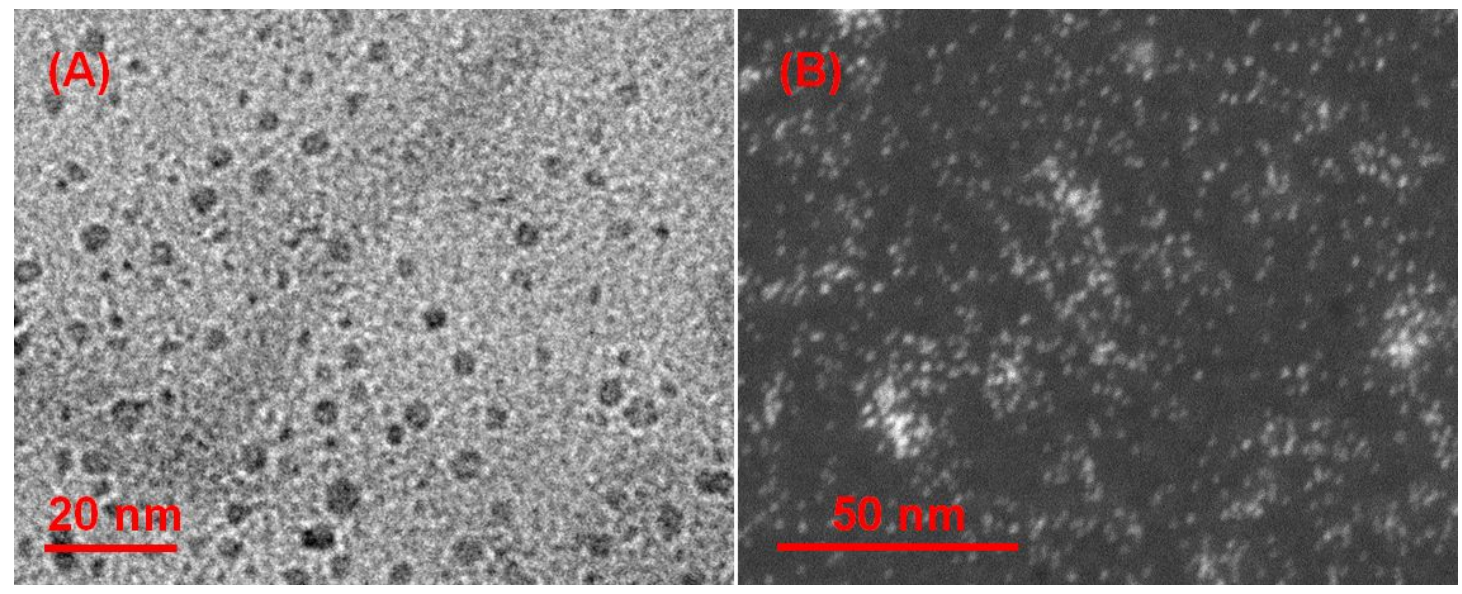

Figure S20. (A) HTEM image of 3 at $20 \mathrm{~nm}$; (B) STEM image of 3 at $50 \mathrm{~nm}$. 


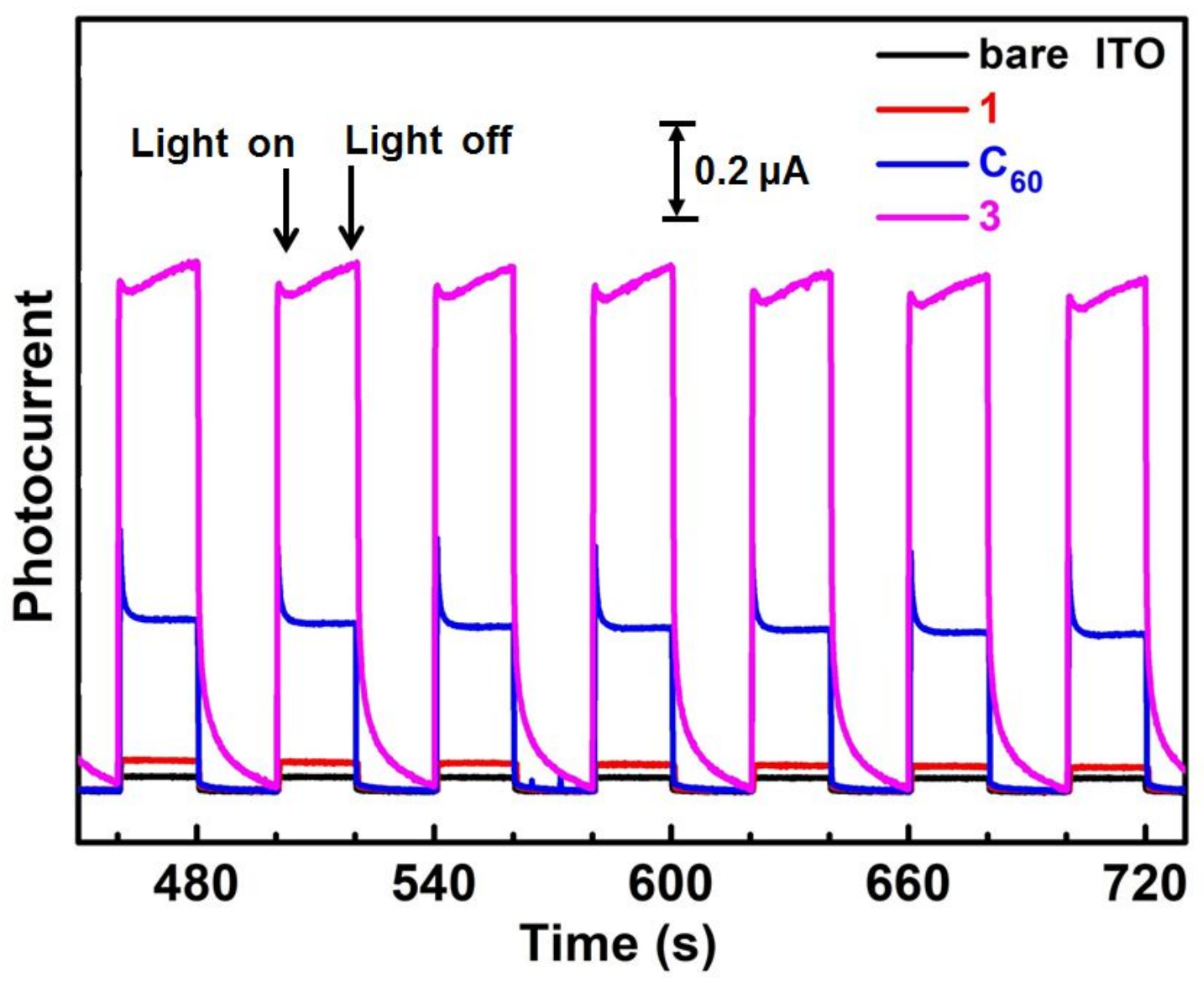

Figure S21. I-t curves for the photocurrent responses of bare ITO, 1, $\mathrm{C}_{60}$ and $\mathbf{3}$ at $\mathrm{E}=0.5 \mathrm{~V}$. 


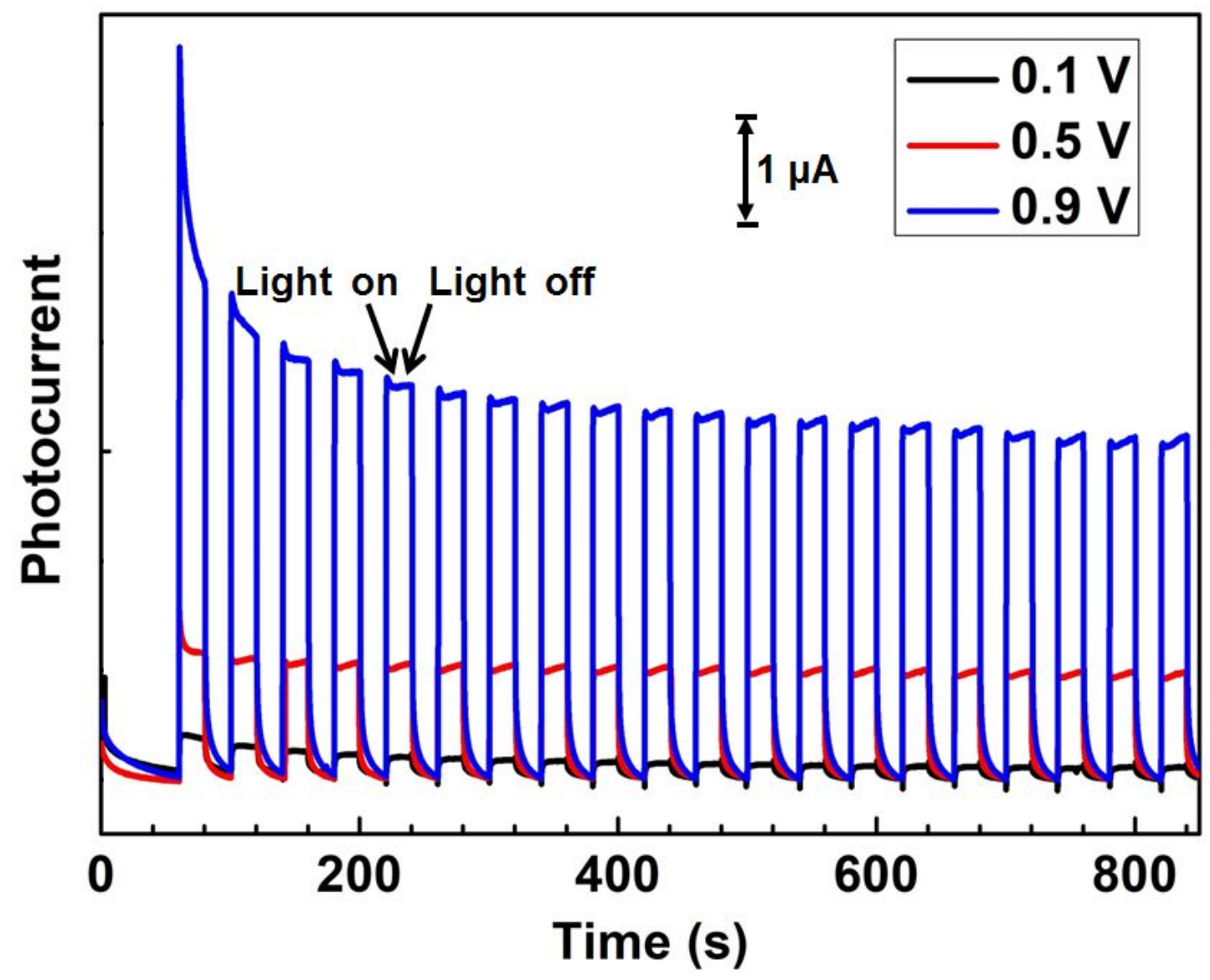

Figure S22. I-t curves for the photocurrent responses of $\mathbf{3}$ at different voltage.

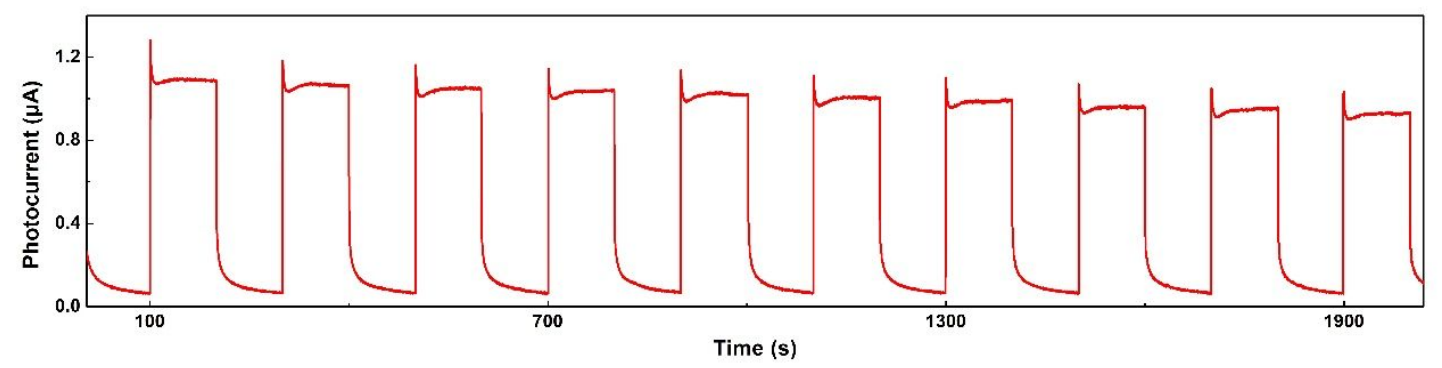

Figure S23. I-t curve for the photocurrent response of 3 at $E=0.5 \mathrm{~V}$. 
10. UV-vis spectra and band gap

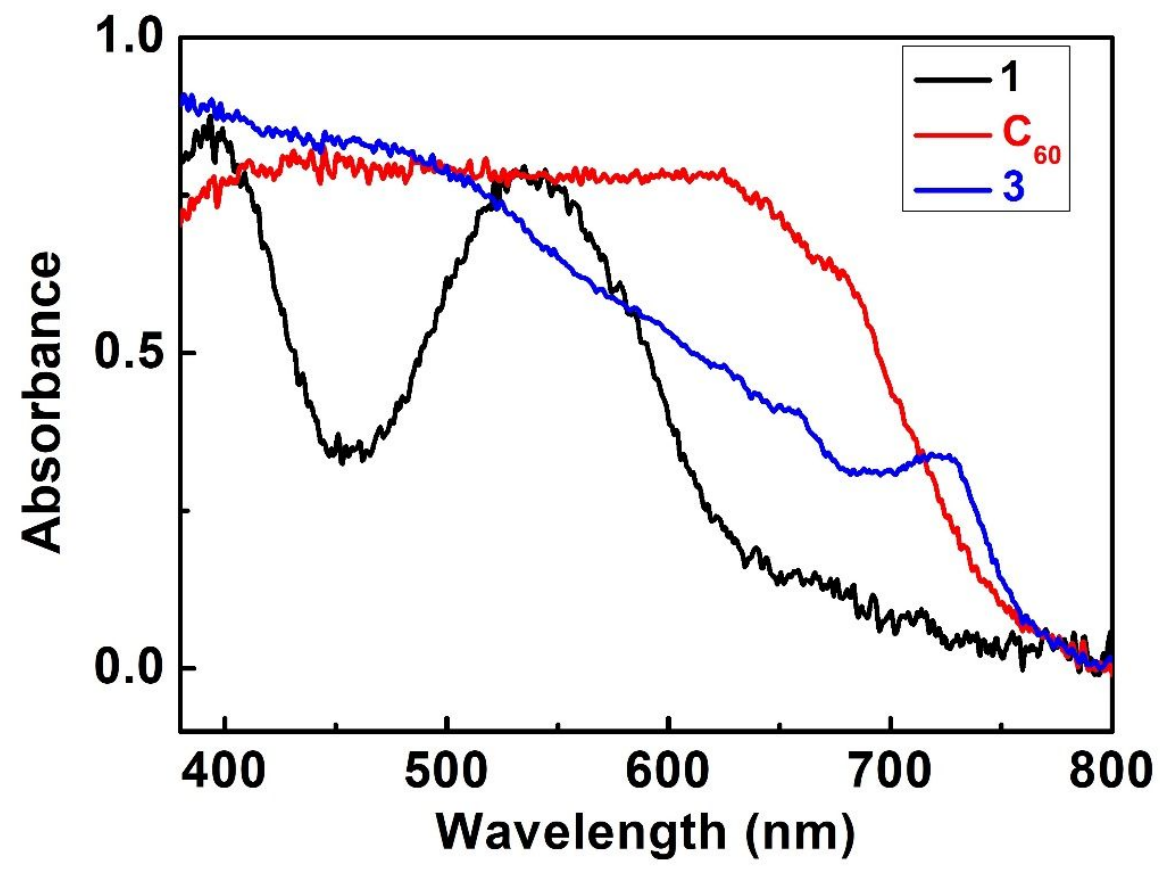

Figure S24. Solid UV spectra of compounds 1, $\mathrm{C}_{60}$ and $\mathbf{3}$.

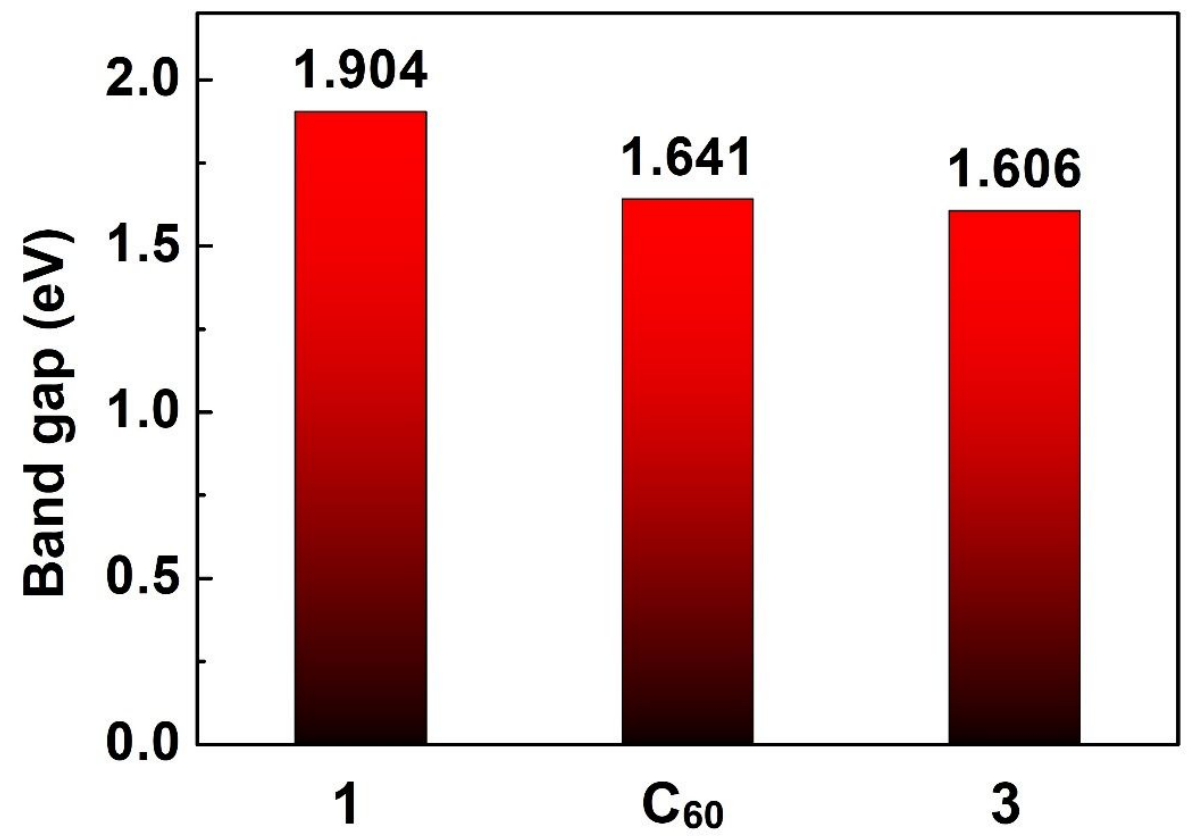

Figure S25. Band gap of $\mathbf{1}$ and $\mathrm{C}_{60}$ and $\mathbf{3}$.

\section{References}

[1] New J. Chem., 2007, 31, 1461-1467.

[2] J. Am. Chem. Soc. 1981, 103, 1865-1867. 